\title{
PENGARUH DIMENSI TERHADAP VOLUME GAS HHO DAN DAYA LISTRIK PADA PROSES ELEKTROLISIS
}

\author{
Dedy Pradigdo', Sudjito Suparman ${ }^{2}$, Agung Sugeng Widodo \\ ${ }^{1}$ Poltekad, Jl. Kesatrian Arhanud - Pendem - Jun Rejo - Batu - Jatim \\ 2Jurusan Teknik Mesin Universitas Brawijaya malang \\ JL. MT. Haryono 167 Malang 65145, Indonesia \\ Email : dedypradigdo@gmail.com
}

\begin{abstract}
The electrode area have an effect on HHO gas production volume, this phenomena influenced by electric power absorbed from the energy source to the electrode. It is necessary to examine how much the influences on process of the water electrolysis. In this research the effect of the electrode total area on the electrolysis process analyzed to determine the volume of $\mathrm{HHO}$ gas and electric power absorbed. The experimental method by testing the extent of several electrodes without the connection and calculating the entire surface on the electrode. The electric power is absorbed among other $L 1=6.413 \mathrm{~mm}^{2}: 5,2 \mathrm{ml}: 0,774$ watt, $L 2=10.028$ $: 28 \mathrm{~mm}^{2}: 7 \mathrm{ml}: 0,9030$ watt, $L 3=14.328 \mathrm{~mm}^{2}: 15 \mathrm{ml}: 2,451$ watt and $L 4=14.3608 \mathrm{~mm}^{2}: 20$ $\mathrm{ml}: 6,192$ watt. In this research, the highest result on the electrode having $24: 14.360,8 \mathrm{~mm}^{2}=$ 6,192-watt area. This result influenced by the surface area reacting with water at the anode and cathode of the 12 Volt $70 \mathrm{AH}$ battery and the capacity of the electrolysis generator.
\end{abstract}

Keywords: Electrode area, Electrolysis, HHO, electric power.

\section{PENDAHULUAN}

Sekitar dua pertiga $\left(3.273 .810 \mathrm{~km}^{2}\right)$ luas wilayah Indonesia merupakan perairan yang keseluruhan luasnya yaitu $5.193 .250 \mathrm{~km}^{2}$, hal tersebut sangat potensial dikembangkan untuk kesejahteraan penduduknya. Usaha ini salah satunya dapat dilakukan dengan menggunakan teknologi tepat guna agar potensi perairan tersebut dapat memenuhi berbagai keperluan masyarakat sekitarnya dan juga agar tidak terjadi kesenjangan energi antar wilayah. Energi alternatif dapat digunakan dengan memanfaatkan air sebagai bahannya, karena didalam air terdapat gas $\mathrm{HHO}$ yang memiliki potensi yang luar biasa bila dimaksimalkan[1].

Penelitian tentang konversi energi pada gas $\mathrm{HHO}$ di Indonesia belum termanfaatkan secara maksimal, potensi yang sangat besar itu dapat diperoleh melalui proses elektrolisis air yang menghasilkan gas $\mathrm{HHO}$. Gas ini termasuk energi yang ramah lingkungan, pemanfaatan gas $\mathrm{HHO}$ dapat bermacammacam untuk pemenuhan kebutuhan hidup manusia. Selain itu energi alternatif ini cocok untuk daerah-daerah terpencil maupun wilayah perbatasan yang sulit dijangkau.
Masyarakat daerah pedalaman dan Prajurit TNI AD yang melaksanakan tugas patroli pengamanan di wilayah sekitar perbatasan belum bisa mengkonversi energi sesuai kebutuhannya. Oleh sebab itu perlu upaya membuat terobosan dengan energi alternatif untuk penggantinya. Misalnya pengganti BBM pada kapal nelayan maupun kapal patroli, energi pengelasan guna memperbaiki peralatan rumah tangga yang terbuat dari plat logam maupun aluminium yang rusak serta sebagai penunjang kehidupan sehari-hari baik kepentingan militer maupun bagi masyarakat sekitarnya[3]. Gas $\mathrm{HHO}$ bisa langsung digunakan, gas tersebut dapat diperoleh dari hasil elektrolisis yang terjadi pada generator yang mudah dibuat. Untuk menghasilkan gas ini dapat menggunakan energi listrik yang tidak terlalu besar. Cukup dari energi listrik berupa baterai, jika habis dapat di charge dengan solar cell sesuai kebutuhan. Berkaitan dengan hal tersebut maka perlu diteliti bagaimana menghasilkan energi yang maksimal dengan memanfaatkan baterai 12 Volt $70 \mathrm{AH}$, melalui proses elektrolisis untuk memproduksi gas $\mathrm{HHO}[2]$. 
Penelitian sebelumnya tentang ini yaitu berpengaruhi terhadap produk hidrogen yang Sopandi (2015), menghasilkan produksi gas sesuai dengan energi yang dikeluarkannya.

$\mathrm{HHO}$ oleh generator $\mathrm{HHO}$ tipe basah dengan metode elektrolisa $\mathrm{H}_{2} \mathrm{O}$. Pada METODE PENELITIAN

penelitian ini menggunakan variasi ketebalan Metode yang digunakan dalam penelitian elektroda jenis stainless steel 304 yaitu 0,8 ini adalah eksperimen untuk mengetahui hasil $\mathrm{mm}, 1 \mathrm{~mm}$ dan $1,2 \mathrm{~mm}$ dengan katalis produksi gas $\mathrm{HHO}$ terhadap variasi luasan $\mathrm{NaHCO}_{3}$ (Natrium Bikarbonat) pada larutan pada katoda-anodanya dengan bahan dari elektrolitnya. Karakteristik yang diketahui stainless stee/ menggunakan energi baterai 12 meliputi konsumsi daya listrik yang digunakan Volt $70 \mathrm{AH}$. Variabel bebas dalam penelitian ini oleh generator, volume gas yang dihasilkan, yaitu variasi luasan katoda dan anoda yang laju produksi gas $\mathrm{HHO}$ yang dihasilkan dan terdiri dari 4 varian, volume air elektrolisis, arus efisiensi generator. Hasil penelitian dan listrik yang dialirkan serta volume air untuk pengujian generator $\mathrm{HHO}$ tipe basah ini pemurniannya yang di gunakan pada waktu didapatkan generator terbaik pada ketebalan pengambilan data saat terjadi proses elektroda $1 \mathrm{~mm}$, diperoleh data hasil elektrolisis. Variabel terikat dalam penelitian ini pengujian dengan daya $\mathrm{HHO}$ yang digunakan adalah hasil proses elektrolisis tersebut berupa sebesar 59,11 Watt, laju produksi gas $\mathrm{HHO}$ gas $\mathrm{HHO}$ dan waktu yang dibutuhkan untuk yang dihasilkan sebanyak $0,00054 \mathrm{~kg} / \mathrm{s}$ dan elektrolisis (tergantung luasan katoda dan efisiensi generator $\mathrm{HHO}$ sebesar $9,42 \%[13]$. anodanya).

Syaiful (2015) membandingkan lapisan pelat-pelat fuel cell yang di variasikan jaraknya dan kuat arus listriknya pada proses elektrolisis menggunakan logam SS316 dan aluminium. Setelah diukur didapatkan kesimpulan yaitu: pemakaian logam SS316 untuk lapisan pelat fuel cell jauh lebih baik dari aluminium karena menghasilkan resistansi lebih rendah dan konstan, laju produksi $\mathrm{HHO}$ pada proses elektrolisis air dipengaruhi oleh variasi lapisan pelat sejajar pada fuel cellnya, nilai resistansi air yang digunakan pada pengukuran ini sebesar $\rho=4710 \Omega$.cm.

Wahyono (2016) pembuatan elektroliser sebagai alat ujinya hanya dengan 2 variasi luasannya hanya permukaan depan belakang saja, samping kanan, kiri, atas, diabaikan, sehingga kurang tajam akurasinya, serta aliran arusnya tidak langsung, sehingga masih terjadinya hambatan arusnya apalagi hanya 10 Amper saja dan konsentrasi air dikataliskan dengan $\mathrm{KOH}$, sehingga pengaruh luasan kurang akurat. Oleh sebab itu maka perlu sekali di teliti tentang bagaimana proses elektrolisis itu dapat menghasilkan hidrogen yang optimal dengan energi yang telah ditentukan, hal itu yang paling dominan diteliti yaitu tentang luasan elektroda yang langsung kontak dengan sistem elektrolisisnya yang

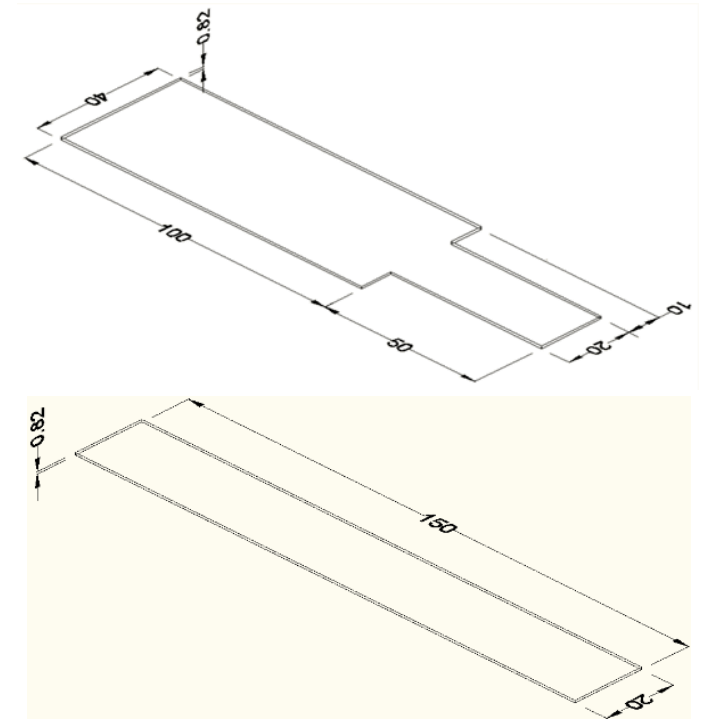

Gambar 1. Variasi elektroda dalam penelitian

Tabel 1. Contoh tabel 1

\begin{tabular}{|c|c|c|c|c|c|c|c|}
\hline 8 & & & & nm) & & & Luasan \\
\hline$\frac{\mathrm{d}}{\omega}$ & L1 & L2 & L3 & $\mathbf{T}$ & P1 & P2 & $\left(\mathrm{mm}^{2}\right)$ \\
\hline I & 20 & - & - & & 150 & - & 6262.4 \\
\hline II & 40 & 10 & 20 & & 100 & 50 & 10028.18 \\
\hline IIII & 60 & 20 & 20 & 0.02 & 100 & 50 & 14328 \\
\hline IV & 80 & 30 & 20 & & 100 & 50 & 14360.8 \\
\hline
\end{tabular}


Sumber energi yang digunakan berasal dari sebuah baterai dengan ukuran 12 volt 70 $\mathrm{AH}$, sedangkan kapasitas air dalam elektrolisernya yaitu $1350 \mathrm{ml}$.

\section{Metode Pengumpulan Data}

Skematik instalasi penelitian dapat dilihat pada Gambar 2. di bawah.

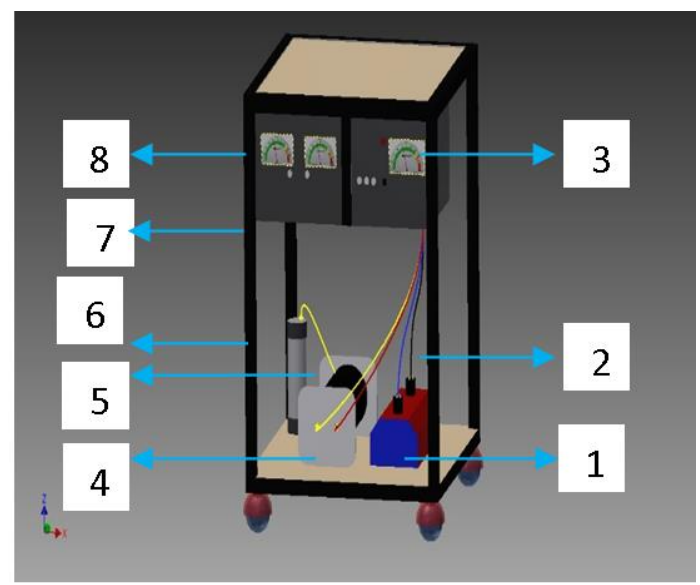

Gambar 2. Skematik Instalasi Penelitian

Bagian-bagian alat :

1. Accu

2. Kabel

3. Indikator tegangan / Aliran Listrik.

4. Reaktor $\mathrm{H}$

5. Selang Saluran Hasil HHO

6. Filter Tank

7. Pipa Saluran H

8. Indikator tekanan $\mathrm{H}$

Metode yang digunakan dalam penelitian ini yaitu true eksperiment / eksperimen nyata secara langsung pada alat elektrolisis ini.

Pada penelitian ini pengambilan datanya dilakukan dengan langkah-langkah sebagai berikut :

Proses pelaksanaan pengambilan data:

a. Hubungkan kabel masing-masing panel ke baterai serta pada alat pengujian, dan pengukuran tegangan dan arus listrik.

b. Bisa dilihat besarnya tegangan DC yang terjadi dan arus yang mengalir dari baterai ke elektrodanya pada skala 12 Volt $70 \mathrm{AH}$. c. Hubungkan alat ukur tersebut diatas dengan baterai dimana kabel merah dengan kutub panel dan positif kabel hitam dengan dengan kutub positif baterai.

d. Catat hasil pengukuran / rekam untuk masing-masing nilai pada alat ukur (waktu prosesnya, arus yang mengalir, dan tegangan yang terjadi serta volume gas HHO nya).

Beban daya listrik yang digunakan merupakan langkah awal dalam merancang sistem elektrolisis yang listriknya dari baterai dengan kapasitas 12 volt $70 \mathrm{AH}$. Berapa volume gas yang dihasilkan selama proses waktu tertentu, hal tersebut tergantung pada daya $(P)$ yang diserap oleh luasan elektrodanya, dalam waktu (t). Untuk memenuhi kebutuhan daya tersebut maka diperlukan perhitungan terhadap besar energi beban yang akan disuplainya sebesar

$$
\mathbf{P}=\mathbf{V} \mathbf{x} \mathbf{I}
$$

Dimana: $P=$ Daya Listrik (Watt)

$$
\begin{aligned}
& \mathrm{V}=\text { Beda tegangan (Volt) } \\
& \mathrm{I}=\text { Arus listrik (Amper) }
\end{aligned}
$$

Untuk memperoleh data yang akurat maka dapat disiasati dengan aliran listriknya ke elektrode dari baterai bisa secara langsung agar dapat mengurangi hambatan. Karena bila menggunakan sambungan maka akan menambah hambatan arus listriknya yang mengalir ke elektrode.

\section{HASIL DAN PEMBAHASAN}

Dalam pembahsan ini maka peneliti berharap mengetahui karakteristik rancang bangun elektrolisis berkaitan dengan proses konsumsi daya yang digunakan selama proses elektrolisis yang memvariasikan luasan elektrodenya.

Dibawah ini merupakan hasil rekapitulasi data-data yang diperoleh dari hasil pengujian sesuai dengan klasifikasi luasan elektrodanya dengan mengambil sampel empat varian elektroda dengan lama prosesnya menggunakan waktu selama 295 menit dan 
pelaksanaan pengambilan datannya tiap 15 hingga mencapai puncaknya / optimalnya yaitu menit sekali. Berikut hasil perhitungan daya menit ke 90 sebesar $5,2 \mathrm{ml}$, setelah itu terjadi listriknya yang telah digunakan selama proses fenomena penurunan volumenya karena elektrolisis yang dihimpun dalam tabel agar energi di baterai mulai menururn juga. Mulai mudah dalam menganalisa data: disalurkan arus listrik dari baterai ke elektroda dengan luasan L2 $10.028,18 \mathrm{~mm}^{2}$ setelah 30 Tabel 2. Data Pengujian menit menunjukan volume $5 \mathrm{ml}$ yang

\begin{tabular}{|c|c|c|c|c|c|c|c|c|c|c|c|c|c|c|c|c|c|c|c|c|c|c|}
\hline \multirow{2}{*}{ No } & \multirow{2}{*}{\begin{tabular}{|c|} 
Variasi \\
Elektroda
\end{tabular}} & \multicolumn{20}{|c|}{ Daya Listrik } & \multirow{2}{*}{ Ket } \\
\hline & & 15 & 30 & 45 & 60 & 75 & 90 & 105 & 120 & 135 & 145 & 160 & 175 & 190 & 205 & 220 & 235 & 250 & 265 & 280 & 295 & \\
\hline 1 & 1 & 0,774 & 0,774 & 0,774 & 0,774 & 0,768 & 0,768 & 0,768 & 0,768 & 0,768 & 0,768 & 0,768 & 0,768 & 0,768 & 0,768 & 0,77 & 0,768 & 0,768 & 0,64 & 0,64 & 0,64 & \\
\hline 2 & II & 0,903 & 0,903 & 0,903 & 0,903 & 0,896 & 0,896 & 0,896 & 0,768 & 0,768 & 0,768 & 0,768 & 0,768 & 0,768 & 0,768 & 0,77 & 0,64 & 0,64 & 0,64 & 0,64 & 0,64 & \\
\hline 4 & IV & 6,063 & 6,192 & 6,192 & 6,192 & 6,192 & 6,192 & 6,144 & 6,144 & 6,144 & 6,016 & 6,016 & 5,969 & 5,969 & 5,969 & 5,8 & 5,796 & 5,796 & 5,625 & 5,625 & 5,63 & \\
\hline
\end{tabular}

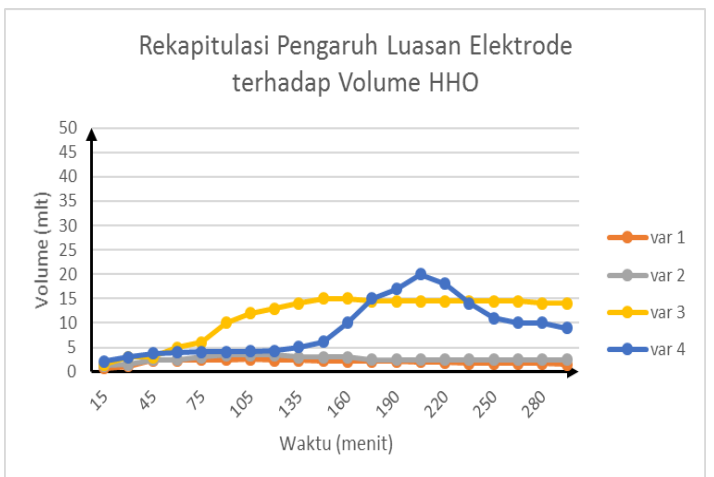

Gambar 3. Rekapitulasi Pengaruh Luasan Elektrode terhadap Volume $\mathrm{HHO}$

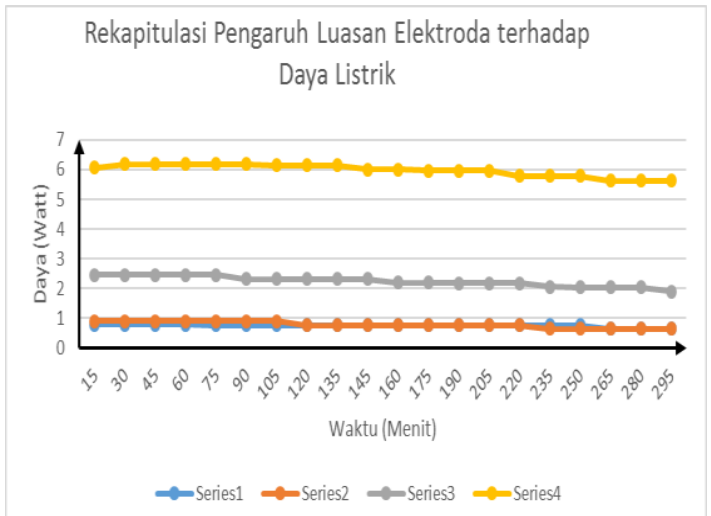

Gambar 4. Rekapitulasi Pengaruh Luasan Elektrode terhadap Daya Listrik

Hasil penelitian menunjukkan bahwa setelah arus listriknya disalurkan dari sumber arus ke electrode, varian ke-1 yang luasannya yaitu L1 6.413,4 mm m $^{2} 30$ menit pertama kurang lebih $4,8 \mathrm{ml}$. Satu jam berikutnya volume meningkat dengan drastis dan meningkat terus selanjutnya naik sedikit, setelah itu terjadi kenaikan yang signifikan antara menit ke 30 hingga 45. Kemudian dilanjutkan lagi pada menit ke 60 hingga mencapai puncaknya dan bertahan tidak lama volume sebesar $7 \mathrm{ml}$ setelah itu menurun lagi sampai $5 \mathrm{ml}$ hingga bertahan lama saat ini, baru menurun lagi.

Mulai disalurkan arus listrik dari baterai ke elektroda dengan luasan L3 $14.328 \mathrm{~mm}^{2}$ pada proses ini awalnya hanya $6 \mathrm{ml}$ saja pada menit ke 30 setelah itu terjadi kenaikan tiap menitnya hinggga pada menit ke 120 mencapai optimalnya yaitu sebesar $15 \mathrm{ml}$ bertahan tidak lama setelah itu mengalami penurunan secara pelan-pelan karena terjadi penurunan daya yang ada dibaterainya.

Saat disalurkan arus listrik dari baterai ke elektroda dengan luasan $L 4=14.360,8 \mathrm{~mm}^{2}$ pada proses ini awalnya kecil saja pada menit ke 160 setelah itu terjadi kenaikan tiap menitnya hingga pada menit ke 205 mencapai maksimalnya yaitu sebesar $20 \mathrm{ml}$ bertahan tidak lama setelah itu mengalami penurunan secara signifikan karena terjadi penurunan energi yang ada dibaterainya.

Bila diakumulasi produksi HHOnya dari keempat variasi luasan elektrodanya maka yang paling optimal hasilnya terdapat pada variasi ke-3 karena dapat menghasilkan volume $\mathrm{HHO}$ cenderung lebih tinggi di banding variasi L1 dan L2 serta beda sedikit dengan L4 yang kenaikan volume maksimalnya memerlukan waktu sekitar 205 menit dan bertahan tidak lama, cenderung kurang optimal karena mengalami penurunan yang tajam setelah itu, sehingga bila diperhatikan maka yang menghasilkan $\mathrm{HHO}$ yang paling optimal 
yaitu pada variasi L3 dikarenakan pengaruh terhadap luasan permukaan yang bersentuhan dengan air mempengaruhi terhadap produksi $\mathrm{HHO}$ nya.

\section{KESIMPULAN}

Keempat variasi eksperimen diatas dengan variasi luasannya $\mathrm{L} 1$ : $6.413 \mathrm{~mm}^{2}$ diperoleh volume dan daya maksimalnya $5,2 \mathrm{ml}$ dan 0,774 watt selama satu jam, L2: $10.028,28$ $\mathrm{mm}^{2}=7 \mathrm{ml}$ dan 0,903 watt selama satu jam, L3: $14.328 \mathrm{~mm}^{2}=15 \mathrm{ml}$ dan 2,451 watt, dan L4: . $14.3608 \mathrm{~mm}^{2}=20 \mathrm{ml}$ selama 15 menit dan 6,192 watt. Pada penelitian ini di peroleh hasil yang paling efektif yaitu pada elektroda L3, karena L3 menghasilkan volume gas $\mathrm{HHO}$ maksimalnya bertahan lama dan mengalami penurunannya sedikit, serta daya listrik yang diserap tidak terlalu besar dibanding $L 4$, sehingga bila dikalkulasi hasilnya paling optimalnya yaitu L3.

\section{UCAPAN TERIMA KASIH}

Mohon terima kasih kami sampaikan tak terhingga kepada keluargaku, Prof. Ir. Sudjito Suparman, Ph.D., Agung. Sugeng Widodo., ST., MT., Ph.D, Kajur Teknik Mesin Universitas Brawijaya, Kaprodi S2 Teknik Mesin Universitas Brawijaya, Para Dosen dan rekan-rekan S2 Teknik Mesin Universitas Brawijaya

\section{DAFTAR PUSTAKA}

[1] Andewi, N.M.A.Y., Hadi, W., 2011, Produksi gas hidrogen melalui proses elektrolisis air sebagai sumber energi, Institut Tekhnologi Sepuluh November, Surabaya.

[2] Attila Gollei, $P €$ eter $G$ orbe, Attila Magyar., Measurement based modeling and simulation of hydrogen generation cell in complex domestic renewable energy systems, Department of Electrical Engineering and Information Systems, Faculty of Information Technology, University of Pannonia, Egyetem Street 10 , Veszprem, H- 8200, Hungary.

[3] A.Syaiful, dkk., 2015, Pengaruh Variasi Lapisan Pelat Sejajar pada Laju Produksi
HHO dari Generator Oxyhydrogen Berbasis Sel Elektrolis, Jurnal fisika dan aplikasinya volume 11, nomor 1 Januari 2015. Institut Teknologi Sepuluh Nopember (ITS), Kampus ITS Sukolilo, Surabaya.

[4] B.N. Lukyanov, D.V. Andreev, V.N. Parmon Boreskov, Catalytic reactors with hydrogen membrane separation Institute of Catalysis, Pr. Akad. Lavrentieva 5, Novosibirsk 630090, Russia.

[5] E.V. Chatzidouros, V.J. Papazoglou, T.E. Tsiourva, D.I. Pantelis, Hydrogen effect on fracture toughness of pipeline steel welds, with in situ hydrogen charging, Shipbuilding Technology Laboratory, School of Naval Architecture and Marine Engineering, National Technical University of Athens, Greece. 4.

[6] Sastrohamidjojo, H., 2005, Kimia Dasar, edisi ke-2, Gadjah Mada University Press, Yogyakarta.

[7] Jack R. Ambler dkk, 2011, Evaluation of stainless steel cathodes and a bicarbonate bufferfor hydrogen production in microbial electrolysis cells using a new method for measuring gas production. Department of Civil and Environmental Engineering, The Pennsylvania State University, University Park, PA 16802.

[8] Marlina, E., dkk., 2013, Produksi Brown's gas hasil elektrolisis $\mathrm{H}_{2} \mathrm{O}$ dengan katalis $\mathrm{NaHCO}_{3}$, Jurnal Rekayasa Mesin, Universitas Brawijaya, Malang.

[9] M. Reytier, S., dkk. 2015, Stack performances in high temperature steam electrolysis and co-electrolysis. CEA, LITEN, 17 rue des Martyrs, F-38054 Grenoble, France.

[10]Natalia R. Kudinova, dkk. 2016 Determining the bound energies of dissolved hydrogen on thebasis of a multichannel diffusion model in a solid. Institute of Problems of Mechanical Engineering RAS, 61 Bolshoi Pr. V.O., St. Petersburg 199178, Russian Federationb Peter the Great St. Petersburg Polytechnic University. 
[11] Selembo, P.A., dkk., 2009, The use of [16]Tong-Le Liu, dkk,. 2016, Evaluation of stainless steel and nickel alloys as lowcost cathodes in microbial electrolysis cells, Journal of Power Sources, volume 190, 271-278.

[12]Perry's, R.H., Green, D.W., 1997, Chemical Engineers Handbook edition 7, McGraw-Hill.

[13] Sopandi, I., dkk., 2015, Studi Ketebalan Elektroda Pada Produksi Gas HHO (Hidrogen Hidrogen Oksigen) Oleh Generator HHo Tipe Basah Dengan Katalis $\mathrm{NaHCO}_{3}$ (Natrium Bikarbonat), Jurnal Ilmiah dan Penerapan Keteknikan Pertanian, Unsyiah.

[14]Rebecca L. King, Gerardine G. Botte , 2016, Hydrogen production via urea electrolysis using a gel electrolyte, Center for Electrochemical Engineering Research, Department of Chemical and Biomolecular Engineering, 165 Stocker Center, Ohio University, Athens, OH 45701, USA.

[15] Tomohiko Imamura dkk, 2009, Control of the ignition possibility of hydrogen by electrostatic discharge at a ventilation duct outlet, Research Core for Explosion Safety, Research Institute of Science for Safety and Sustainability, National Institute of Advanced Industrial Science and Technology (AIST), 16-1 Onogawa, Tsukuba, Ibaraki 305-8569, Japan. polarization and hydrogen production efficiency of solid oxide electrolysis stack with La0.6Sro.4Co0.2Fe0.8O3-ס $\mathrm{Ce}_{0.9} \mathrm{Gd}_{0.1} \mathrm{O}_{1.95}$ oxygen electrode, Institute of Nuclear and New Energy Technology, Tsinghua University, Beijing, 100084, China.

[17]Wahyono, 2016. Pembuatan alat produksi gas hidrogen dan oksigen tipe wett cell dengan variasi luas penampang, Jurnal Polines.

[18] Yimin Zhang, Matthew D. Merrill, Bruce E. Logan, The use and optimization of stainless steel mesh cathodes in microbial electrolysis cells, Department of Civil and Environmental Engineering, Penn State University, 212 Sackett Building, University Park, PA 16802, USA.

[19] Yousif M. Hamad, dkk., 2014, A design for hydrogen production and dispensing for northeastern United States, along with its infrastructural development timeline, Department of Mechanical and Aerospace Engineering, Missouri University of Science andTechnology Rolla, MO, USA. 